\title{
Regulation of Messenger RNAs for the Hydrophobic Surfactant Proteins in Human Lung
}

\author{
Helen G. Liley, ${ }^{\star \ddagger}$ R. Tyler White, ${ }^{5}$ Rhonda G. Warr, ${ }^{5}$ Bradley J. Benson, ${ }^{5}$ Samuel Hawgood, ${ }^{*}$ and Philip L. Ballard* \\ *Department of Pediatrics and the Cardiovascular Research Institute, University of California, San Francisco, California 94143 ; \\ ${ }^{\ddagger}$ Department of Pediatrics, Mount Zion Medical Center, San Francisco, California 94121; and \\ ${ }^{\S}$ California Biotechnology, Inc., Mountain View, California 94043
}

\begin{abstract}
The pulmonary surfactant proteins SP-B (8,000 D) and SP-C $(4,000 \mathrm{D})$ accelerate surface film formation by surfactant phospholipids. We used cDNA probes to examine regulation of these proteins in human fetal lung. The mRNAs were detectable at 13 wk gestation and increased to $\sim 50 \%$ (SP-B) and $\sim 15 \%$ (SP-C) of adult levels at 24 wk. The mRNAs were detected only in lung of 11 dog tissues examined. When human fetal lung was cultured as explants without hormones, SP-B mRNA increased and SP-C mRNA decreased. Exposure for $\mathbf{4 8}$ $h$ to glucocorticoids, but not other steroids, increased both SP-B mRNA ( 4-fold) and SP-C mRNA ( 30-fold) vs. controls. Half-maximal stimulation occurred with $1 \mathrm{nM}$ dexamethasone and $300 \mathrm{nM}$ cortisol for SP-B mRNA and at threeto fivefold higher concentrations for SP-C mRNA. Both stimulation and its reversal on removal of hormone were more rapid for SP-B than for SP-C. Terbutaline and forskolin increased SP-B mRNA but not SP-C mRNA. Levels of both mRNAs were much higher in type II cells than fibroblasts prepared from explants. Thus, the genes for SP-B and SP-C are expressed in vivo before synthesis of both SP-A (28,000-36,000 D) and surfactant lipids. Glucocorticoid induction of SP-B and SP-C mRNAs in type II cells appears to be receptor mediated but may involve different mechanisms.
\end{abstract}

\section{Introduction}

Pulmonary surfactant lowers the surface tension within lung alveoli, allowing for normal respiration. In addition to surface active phosphatidylcholine and other phospholipids, surfactant contains at least three proteins that are thought to be important for surfactant structure and function. The surfactant proteins have been designated SP-A (glycoprotein of

Preliminary reports of some of these findings have appeared in Ballard, P. L., S. Hawgood, G. A. Wellenstein, H. G. Liley, B. J. Benson, and R. T. White. 1987. Surfactant protein of 18,000 dalton (SP-18) in human fetal lung. Pediatr. Res. 21:442A (Abstr.), and Liley, H. G., P. L. Ballard, S. Hawgood, R. G. Warr, R. T. White, and B. J. Benson. 1988. Regulation of mRNA for the $5 \mathrm{kDa}$ surfactant protein (SP-C) in human fetal lung. Pediatr. Res. 23:247A. (Abstr.)

Address correspondence to Dr. Philip L. Ballard, Cardiovascular Research Institute, Box 0130, University of California, San Francisco, San Francisco, CA 94143.

Received for publication 12 August 1988 and in revised form 17 October 1988.

J. Clin. Invest.

(c) The American Society for Clinical Investigation, Inc.

0021-9738/89/04/1191/07 \$2.00

Volume 83, April 1989, 1191-1197
28,000-36,000 D), SP-B (hydrophobic protein of $\sim 8,000 \mathrm{D}$ ), and SP-C (hydrophobic protein of $\sim 4,000 \mathrm{D})$ (1). The hydrophobic proteins markedly increase the rate of adsorption of surfactant phospholipids to the air-aqueous interface and appear to be important components of replacement surfactant preparations that are being tested clinically for treatment of hyaline membrane disease in premature infants (1-8).

The hydrophobic proteins have recently been purified and their cDNAs sequenced. SP-B arises from a 42,000-D precursor protein that undergoes both amino and carboxy-terminal processing to produce the active peptide $\left(M_{\mathrm{r}}=18,000\right.$ unreduced). SP-C is formed from a precursor protein of $\sim 21,000$ $\mathrm{D}$ and contains an unusual polyvaline domain. The genes for the two proteins are located on different chromosomes in the human $(2,3,9-12)$.

Maturation of the fetal lung, including the surfactant system, is known to be under hormonal regulation (13). Synthesis of surfactant phosphatidylcholine is increased by glucocorticoids, thyroid hormones, and agents that increase intracellular cAMP. Prenatal glucocorticoid treatment is used to reduce the incidence of hyaline membrane disease in prematurely born infants (13). Recent studies indicate that synthesis of SP-A and its mRNA is also affected by various hormones. Synthesis of SP-A is stimulated by low concentrations of glucocorticoids (and inhibited in human lung by higher concentrations and longer exposures) and by cAMP (14-22). There are also reports that SP-A synthesis is stimulated by epidermal growth factor and inhibited by both transforming growth factor- $\beta$ and insulin $(22,23)$.

In the present study we have examined the developmental and hormonal regulation of the mRNAs for SP-B and SP-C in fetal human lung. We find that there is increasing expression of both genes during the second trimester and that glucocorticoids stimulate expression of both during explant culture. The properties of the induction processes suggest different mechanisms of pretranslational regulation of SP-B and SP-C synthesis.

\section{Methods}

Tissue culture and cell isolation. Adult human lung was obtained at pneumonectomy and fetal tissue from second trimester therapeutic abortuses under protocols approved by the Committee on Human Research at the University of California, San Francisco. Lung and other tissues were also obtained from newborn and adult dogs. Human fetal lung was studied freshly (preculture) and after explant culture (24) in serum-free Waymouth's medium and an atmosphere of $95 \%$ air $/ 5 \%$ $\mathrm{CO}_{2}$ for $1-8 \mathrm{~d}$ with daily changes of medium. Dexamethasone (10 $\mathrm{nM}$, unless otherwise stated) or other hormones were added to some cultures after $24 \mathrm{~h}$ of culture. Explants were harvested (generally after $72 \mathrm{~h}$ of culture) and stored at $-70^{\circ} \mathrm{C}$ for preparation of RNA. Enriched populations of type II cells and fibroblasts were isolated by a differen- 
tial adherence procedure from explants cultured for $5 \mathrm{~d}$ with dexamethasone $(10 \mathrm{nM})$ and $\mathrm{T}_{3}(2 \mathrm{nM})(25)$.

Isolation of RNA and DNA hybridization. RNA was isolated from tissue (generally $50-100 \mathrm{mg}$ wet $\mathrm{wt}$ ) by the guanidinium isothiocyanate technique as previously described (14). To assess mRNA size, electrophoresis was done in $1.2 \%$ agarose gels in the presence of glyoxal and SDS, and major rRNA bands were visualized with ethidium bromide. RNA was transferred to nitrocellulose paper by blotting and hybridized with ${ }^{32} \mathrm{P}$-labeled human cDNAs for SP-B and SP-C as described below. To measure mRNA content, specific amounts of RNA (usually 0.5-4 $\mu \mathrm{g}$ ) were applied to nitrocellulose filters for dot blot analysis. Each blot also contained various amounts $(0.25-2 \mu \mathrm{g})$ of adult human lung RNA (pooled in equal amounts from four specimens); when probed individually, the adult samples varied by a maximum of 1.5and 2.1-fold for content of SP-B mRNA and SP-C mRNA, respectively. Hybridization with cytosol of isolated cells was performed by the cytoblot method of White and Bancroft (26). Hybridization for SP-B and SP-C mRNAs was carried out with ${ }^{32}$ P-labeled dog or human cDNA probes prepared by nick translation. Each cDNA contains nearly the entire coding sequence for the SP-B or SP-C precursor protein as previously described $(2,3)$. In control experiments some blots were reprobed with ${ }^{32} \mathrm{P}$-labeled cDNA for the $\alpha$ chain of the GTP-binding regulatory protein of adenylate cyclase $\left(G_{s}\right)$ or for actin $(27,28)$. Before reprobing with a different cDNA, blots were boiled in water for $10 \mathrm{~min}$.

The hybridization reaction used $\sim 3 \times 10^{5} \mathrm{cpm} / \mathrm{ml}$ of labeled probe and was done for $16 \mathrm{~h}$ at $40^{\circ} \mathrm{C}$ in $50 \%$ formamide, $5 \times$ standard saline citrate (SSC; $1 \times \mathrm{SSC}$ is $0.15 \mathrm{M} \mathrm{NaCl}, 0.015 \mathrm{M}$ sodium citrate at pH 7.5), 0.05\% SDS, 10× Denhardt's solution (0.02\% BSA, $0.02 \%$ Ficoll, $0.02 \%$ polyvinylpyrrolidone), $50 \mu \mathrm{g} / \mathrm{ml}$ of denatured and sheared salmon sperm DNA, 0.005 M EDTA, 0.05 M Hepes, pH 7 . After washing twice for $30 \mathrm{~min}$ at $50^{\circ} \mathrm{C}$ in $0.2 \times \mathrm{SSC}, 0.1 \% \mathrm{SDS}$, the blots were applied to Kodak XAR film with Cronex intensifying screens (DuPont Instruments, Wilmington, DE) for autoradiography (1-10 d). Developed films were scanned with a soft laser densitometer, and relative densities were calculated from linear portions of the doseresponse curve of each RNA. Data for content of SP mRNAs of fetal lung are expressed as percent of the adult value (from the same blot). Statistical analyses used linear regression and analysis of variance.

\section{Results}

Ontogeny in human lung. The human cDNA probes were used to assess the size of mRNAs for SP-B and SP-C in fetal and adult lung. The mRNA for each protein appeared as a single major band on Northern analysis (Fig. 1). The mRNAs for SP-B and SP-C were $\sim 2.1$ and $0.9 \mathrm{~kb}(n=3)$, respectively, for both preculture and cultured tissue. Identical results were obtained with adult tissue (not shown). These sizes are consistent with the lengths of the derived coding sequences for the two proteins $(2,3,9-11)$.

The content of mRNAs was determined by dot blot hybridization and scanning densitometry of autoradiograms. Results with preculture lung tissue are shown in Fig. 2. mRNA for both proteins was present at low levels at 13 wk gestation. The content increased during the second trimester in an exponential fashion, reaching $\sim 50$ and $15 \%$ of the pooled adult level at 24 wk for SP-B and SP-C, respectively.

To investigate whether the levels of the SP-B and SP-C mRNAs are correlated, we compared levels in 12 additional lungs of 21-22 wk gestation. There was a weak correlation $(r$ $=0.41$ ) between the two mRNAs. As a control experiment, the blots were reprobed with cDNA for $\mathrm{G}_{\mathrm{s} \alpha}$. Correlation coefficients for SP-B mRNA and SP-C mRNA vs. $G_{s \alpha}$ mRNA were 0.71 and 0.45 , respectively. These findings indicate that the

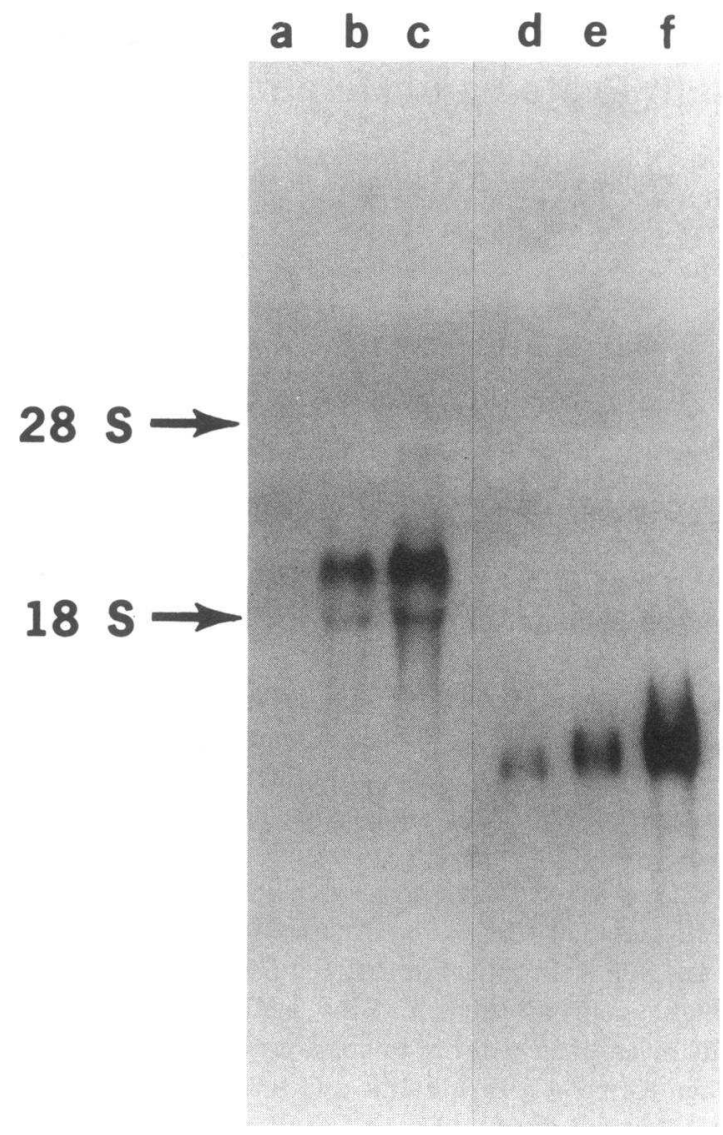

Figure 1. Northern RNA blot analysis of SP-B and SP-C mRNAs from human fetal lung. Approximately $20 \mu \mathrm{g}$ of RNA from preculture lung (lanes $a$ and $d$ ), control explant culture for $5 \mathrm{~d}$ (lanes $b$ and $e$ ), and dexamethasone-treated explants (lanes $c$ and $f$ ) were applied to agarose gels. Lanes $a-c$ were probed with SP-B cDNA; lanes $d-f$ were probed with SP-C cDNA. The location of $18 \mathrm{~S}$ and $28 \mathrm{~S}$ rRNA as detected by ethidium bromide staining are indicated. $A$ band at $2.1 \mathrm{~kb}$ was detected in lane $a$ on longer exposure of the film.

relative levels of SP-B and SP-C mRNAs in individual lungs correlate no better with each other than with mRNA for a protein unrelated to surfactant.
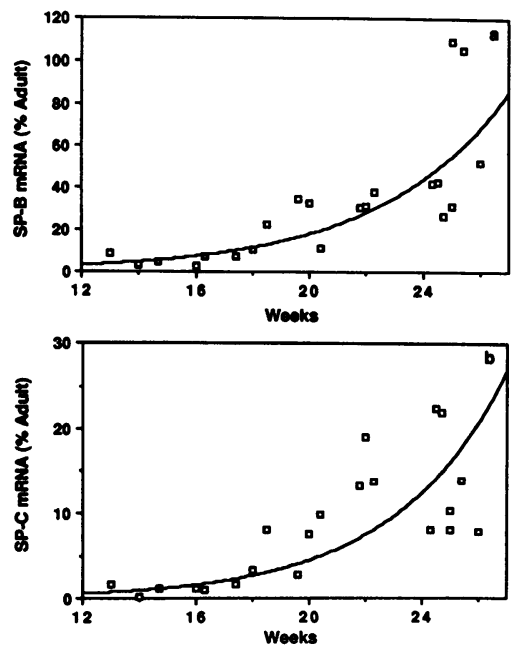

Figure 2. Developmental pattern for $S P$ mRNAs during the second trimester. RNA was prepared from 21 specimens of human fetal lung and analyzed on dot blots for levels of SP-B mRNA $(a)$ and SP-C mRNA $(b)$. The data are expressed as percent of the value for adult lung and computer-derived exponential curves are shown. 
Distribution among dog tissues. We studied the tissue distribution of SP-B and SP-C mRNAs using canine cDNA probes. RNA was prepared from 2 specimens of lung and from 10 other newborn dog tissues. SP-C mRNA was detected in lung but not kidney, stomach, liver, thymus, adrenal, heart, intestine, spleen, ovary, or muscle (Fig. 3). When the dot blot was washed and reprobed with cDNA for $G_{s \alpha}$, mRNA was detected in every tissue (data not shown).

In tissues from adult dogs, mRNA for SP-C was present in adult lung tissue at about three times the concentration in newborn lung. Among the same 10 other adult tissues there was no detectable hybridization except for a faint signal with spleen ( $<0.3 \%$ of the lung value). In similar studies with SP-B cDNA, hybridizable RNA was detected only in lung tissue of both newborn and adult dogs (data not shown).

Effect of culture and glucocorticoids. To examine regulation of SP-B and SP-C mRNAs in vitro, human fetal lung tissue was maintained in explant culture in the presence or absence of dexamethasone ( $10 \mathrm{nM})$ or other steroids. The effects of culture and dexamethasone treatment are summarized in Table I. The content of SP-B mRNA increased during explant culture in the absence of serum or hormones. In contrast, levels of SP-C mRNA decreased initially (low or undetectable on days 1-3 of culture), then increased but were still below the preculture level at day 5 . Treatment with $10 \mathrm{nM}$ dexamethasone increased the content of SP-B mRNA 2- to 4-fold over control (no hormone) and increased levels of SP-C mRNA by 20- to 30-fold; maximal stimulation occurred on day 3 for both mRNAs. Levels of mRNA for both proteins were also higher after dexamethasone treatment compared with preculture levels. By contrast, there were no consistent effects of culture or dexamethasone treatment on levels of mRNA for actin and $\mathrm{G}_{\mathrm{s} \alpha}$ (data not shown).

Dexamethasone stimulation was also examined as a function of time of exposure to hormone (Fig. 4). In these experiments the explants were all cultured for $76 \mathrm{~h}$ with addition of $10 \mathrm{nM}$ dexamethasone at various times before harvesting the tissue. Levels of both mRNAs were significantly increased after $10 \mathrm{~h}$ exposure to dexamethasone and reached maximal values by $30 \mathrm{~h}$. The time required for half-maximal stimulation under these conditions was somewhat less for SP-B $(\sim 14$ h) than for SP-C $(\sim 19 \mathrm{~h})$.

Fig. 5 shows the effect in one experiment (representative of three) of a brief exposure to cortisol. Explants were treated with diluent (control) or cortisol $(1 \mu \mathrm{M})$ beginning on day 1 of culture. The hormone was removed from some cultures $24 \mathrm{~h}$ later (day 2) by changing the culture medium three times at 2-h intervals. Cortisol was chosen for these experiments because of its relatively fast dissociation from glucocorticoid receptors (29). Removal of cortisol blocked any further increase in SP-C mRNA content and diminished the response for SP-B mRNA; by day 4-5 levels in cultures treated briefly with cortisol were similar to control values.

Fig. 6, $A$ and $B$ presents results of dose-response studies with dexamethasone. Explants were cultured for $72 \mathrm{~h}$ with addition of dexamethasone after $24 \mathrm{~h}$ of culture (i.e., 48-h exposure to hormone); induction of both mRNAs is maximal under these conditions (Table I, Fig. 4). SP-B mRNA was stimulated half-maximally at a concentration of $\sim 1 \mathrm{nM}$ and the greatest response occurred with $10 \mathrm{nM}$ dexamethasone. Stimulation of SP-C mRNA content was evident at $1 \mathrm{nM}$, half maximal at $\sim 5 \mathrm{nM}$, and optimal at $\sim 10 \mathrm{nM}$.

\section{Lung 1}

Kidney

\section{Stomach}

\section{Liver}

Thymus

\section{Adrenal}

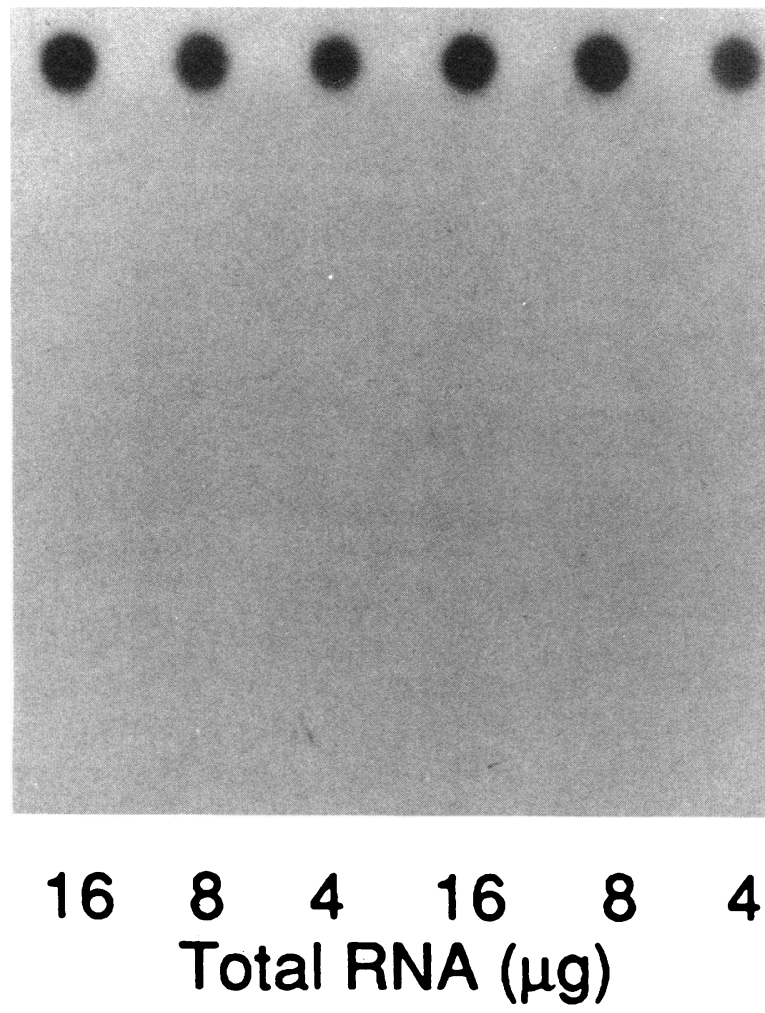

Lung 2 Heart

\section{Intestine}

\section{Spleen}

\section{Ovary}

\section{Muscle}

Figure 3. Dot blot of SP-C mRNA in newborn dog tissues. RNA was prepared from two specimens of lung and from other tissues as shown. Relatively large amounts of RNA were applied to the blot and the film was overexposed to detect low levels of hybridization. 
Table I. Effect of Explant Culture and Dexamethasone on SP mRNAs

\begin{tabular}{llclll}
\hline & \multicolumn{2}{c}{ SP-B mRNA } & & \multicolumn{2}{c}{ SP-C mRNA } \\
\cline { 2 - 3 } \cline { 5 - 6 } Days in culture & \multicolumn{2}{c}{ Control } & Dexamethasone & Control & Dexamethasone \\
\hline & & \multicolumn{4}{c}{$\%$ of adult level } \\
0 (preculture) & $24.5 \pm 3.9$ & & $6.9 \pm 1.1$ & \\
3 & $48.5 \pm 6.4$ & $202.9 \pm 19.9$ & $0.4 \pm 0.1$ & $13.6 \pm 2.6$ \\
5 & $86.9 \pm 16.9$ & $182.0 \pm 34.8$ & $1.4 \pm 0.5$ & $30.5 \pm 7.3$ \\
\hline
\end{tabular}

Levels of SP-B mRNA and SP-C mRNA were determined in fetal lung tissue before (preculture) and after explant culture in the absence (control) or presence of dexamethasone $(10 \mathrm{nM})$, added after $24 \mathrm{~h}$ of culture. Values are mean $\pm \mathrm{SE}$ ( $n=8-17$ experiments). $P$ $<0.05$ for dexamethasone-treated vs. control at 3 and $5 \mathrm{~d}$ for both SP-B and SP-C.

We also performed dose-response studies with cortisol (Fig. 6, $C$ and $D$ ). Induction of SP-B mRNA was half maximal at $\sim 300 \mathrm{nM}$ and optimal at $\sim 1 \mu \mathrm{M}$. Half-maximal stimulation of SP-C mRNA occurred at $\sim 1 \mu \mathrm{M}$ and was optimal at $\geq 10 \mu \mathrm{M}$.

The effect of various other steroids on induction of SP-B and SP-C mRNAs was determined (Fig. 7). In these experiments explants were exposed to $10 \mathrm{nM}$ dexamethasone or 1 $\mu \mathrm{M}$ concentrations of other steroids for $48 \mathrm{~h}$. There was no stimulation with estradiol, dihydrotestosterone, or $17 \alpha$-hydroxyprogesterone; stimulation was similar with dexamethasone and three natural corticosteroids (cortisol, cortisone, and corticosterone). These findings are consistent with a receptormediated process for induction of both mRNAs.

Cellular localization of $S P$ PRNAs. Fetal lung contains predominantly mesenchymal fibroblasts and epithelial cells, plus relatively small numbers of endothelial and other cell types. To examine the cellular localization of SP mRNAs, we prepared partially purified populations of type II epithelial cells (78-92\% pure) and fibroblasts (81-97\% pure) from hormone-treated explants. The content of mRNAs for SP-B and SP-C was determined in four preparations of freshly isolated

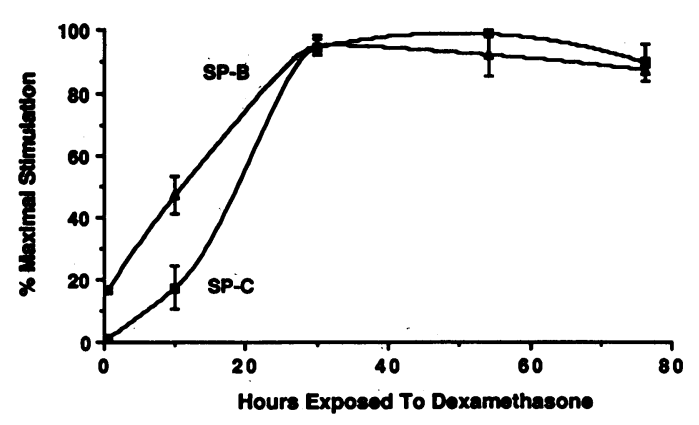

Figure 4. Time course of SP mRNAs after exposure to dexamethasone. Explants were cultured for $76 \mathrm{~h}$ with addition of $10 \mathrm{nM}$ dexamethasone at initiation of culture ( $76 \mathrm{~h}$ exposure) or after 22,46 , and $66 \mathrm{~h}$ of culture $(54,30$, and $10 \mathrm{~h}$ exposure, respectively). Data are mean $\pm \mathrm{SE}$ for three experiments and are expressed as percent of the maximal value in each experiment.
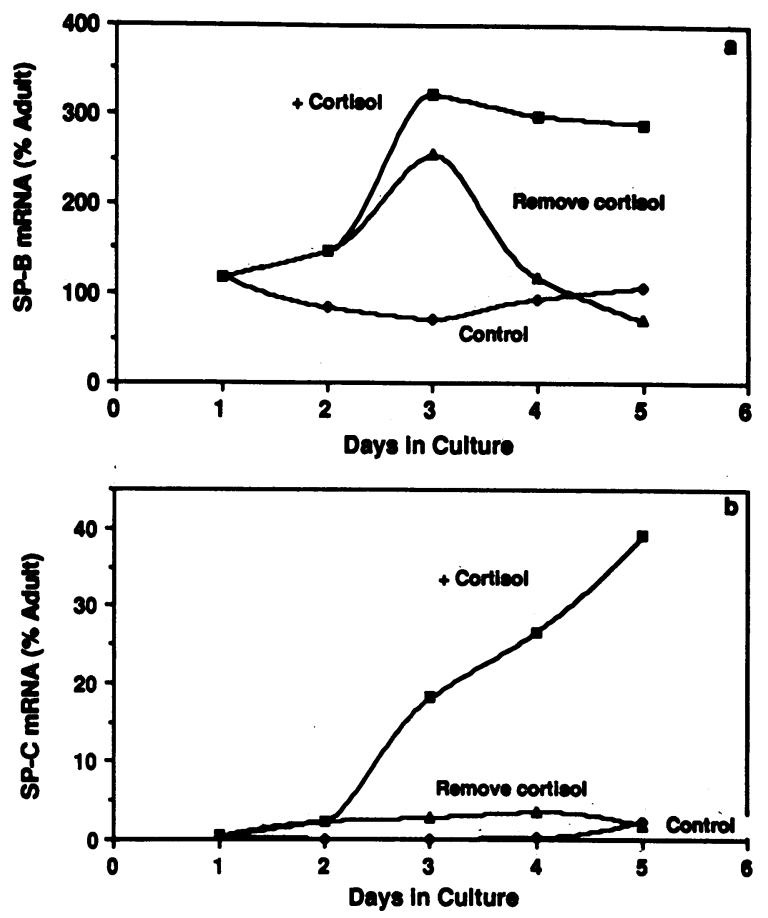

Figure 5. Effect of removing cortisol on levels of SP mRNAs. Explants of a 19.6-wk gestation lung were cultured without hormone (control) or with $1 \mu \mathrm{M}$ cortisol added on day 1 . Cortisol was removed from some culture dishes on day 2 (remove cortisol) by repeated media changes. (a) SP-B mRNA; (b) SP-C mRNA.

cells by both RNA blot and cytoblot (see Methods). The type II cell populations contained $6->100$ times more SP-B mRNA and 11-50 times more SP-C mRNA than the fibroblast populations.

Effect of CAMP. We also examined the effect of agents that increase intracellular cAMP. As shown in Table II, treatment of explants for $2 \mathrm{~d}$ with forskolin or terbutaline increased SP-B mRNA levels but had no effect on SP-C mRNA. The response of SP-B mRNA to treatment with dexamethasone plus either terbutaline or forskolin was no greater than with dexamethasone alone.

\section{Discussion}

These studies have examined regulation of SP-B and SP-C mRNAs both in vivo and in vitro. mRNA for both proteins was detected in human lung as early as 13 wk gestation, and levels increased exponentially during the second trimester. By contrast, neither SP-A nor its mRNA are consistently detected in lung specimens of 24 wk gestation or less $(14,15,18)$. Although some lamellar bodies are found in lung epithelial cells by $24 \mathrm{wk}$, the major increase in saturated phosphatidylcholine (reflecting accumulation of surfactant phospholipids) occurs after 24 wk (14). Thus, expression of the genes for the two hydrophobic proteins begins before differentiation of type II cells and before increased synthesis of surfactant lipids and SP-A. In studies with adult rat lung, SP-B mRNA has been detected in both alveolar type II cells and selected cells of the bronchial epithelium (30).

At all gestational ages studied, SP-B mRNA was more abundant (compared with adult levels) than SP-C mRNA. 

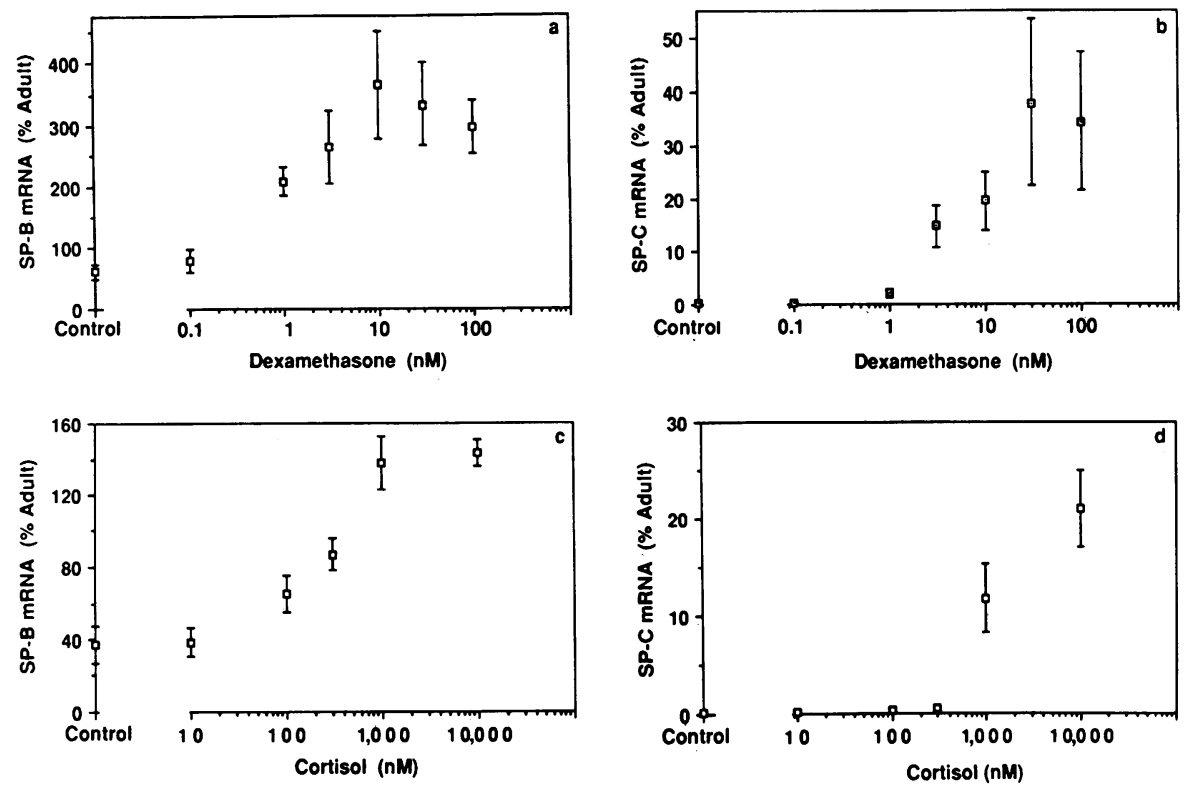

\begin{abstract}
Figure 6. Dexamethasone and cortisol dose response for SP mRNAs. Explants were cultured for $3 \mathrm{~d}$ in the presence of dexamethasone $(a$ and $b$ ) or cortisol ( $c$ and $d$ ) at various concentrations for the last $48 \mathrm{~h}$ of culture. Data are mean $\pm \mathrm{SE}$ for three (cortisol) or four (dexamethasone) experiments for SP-B ( $a$ and $c)$ and SP-C ( $b$ and d) mRNAs.
\end{abstract}

Levels for both messages were generally less in preculture fetal tissue than in adult lung although there was considerable variability later in the second trimester. Despite the similar in vivo developmental patterns, the two genes appear to be independently regulated. In lung samples of 21-22 wk the correlation between levels of SP-B and SP-C mRNAs was no stronger than the correlation with an mRNA $\left(G_{s \alpha}\right)$ that is unrelated to pulmonary surfactant and is not influenced by glucocorticoids.

We studied tissue distribution of the surfactant protein mRNAs in a variety of dog tissues. SP-B mRNA was detected only in lung tissue. Results were the same for SP-C mRNA except for a low level of hybridizable mRNA in adult but not newborn spleen. The hybridization observed in adult spleen most likely reflects the presence of an mRNA similar to SP-C mRNA. These data suggest that the hydrophobic surfactant proteins are expressed only in lung tissue.

Explant culture has been a useful approach to investigating regulation of surfactant components. When fetal tissue is cultured in the absence of serum or hormones, changes occur that are consistent with differentiation of type II cells (reviewed in reference 13). It has been proposed that this process reflects precocious lung maturation, perhaps secondary to removal of

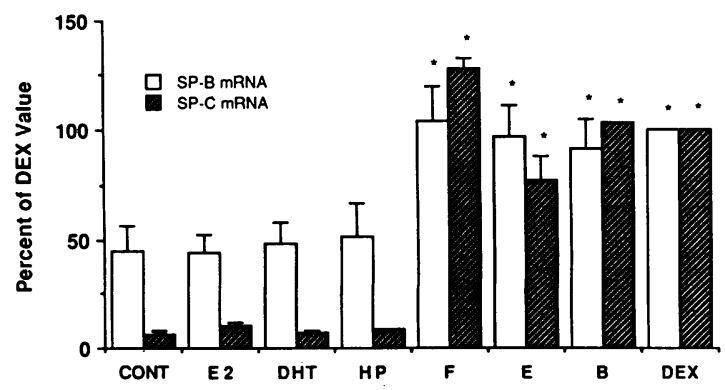

Figure 7. Effect of various steroids on SP mRNAs. Explants were treated with $10 \mathrm{nM}$ dexamethasone or $1-\mu \mathrm{M}$ concentrations of other steroids. Data are mean $\pm S E$ for three experiments with the dexamethasone value assigned $100 \%$. Cont, control; E2, 17 $\beta$-estradiol; $D H T$, dihydrotestosterone; $H P, 17 \alpha$-hydroxyprogesterone; $F$, cortisol; $E$, cortisone; $B$, corticosterone; $D E X$, dexamethasone. ${ }^{*} P<0.05$ vs. control. an inhibitory factor. In the present study we found that expression of the SP-B gene also increased during explant culture in the absence of serum or hormones, reaching levels comparable to those in adult tissue. However, SP-C mRNA decreased initially during explant culture and was again detected at low levels after $5 \mathrm{~d}$. The decrease in SP-C mRNA levels was an unexpected finding in view of the increases observed for other developmentally regulated proteins and processes of fetal lung cells. Our results differ from those of Whitsett et al. (20), in which increases in mRNA for both hydrophobic proteins were observed (but not quantitated). In previous studies with human lung, SP-A mRNA was not detected in preculture tissue, appeared by the third day of culture, and increased 10-fold by day $5(14,15,18)$. These findings suggest independent regulation of the genes for the three surfactant proteins during culture in the absence of hormones.

We find that accumulation of mRNAs for both hydrophobic proteins is stimulated by dexamethasone, agreeing with the recent results of Whitsett et al. (20). In our time-course studies, mRNA levels for both proteins were detectable within $10 \mathrm{~h}$ of exposure to dexamethasone and maximal stimulation occurred by $48 \mathrm{~h}$. The increase in SP-B mRNA was somewhat

Table II. Effect of Activators of Adenylate Cyclase on SP mRNAs

\begin{tabular}{|c|c|c|}
\hline & \multicolumn{2}{|c|}{ mRNA } \\
\hline & SP-B & SP-C \\
\hline & \multicolumn{2}{|c|}{$\%$ of adult level } \\
\hline Control & $58.3 \pm 14.4$ & $<0.3$ \\
\hline Dexamethasone (10 nM) & $260.2 \pm 64.2^{*}$ & $10.6 \pm 5.5^{*}$ \\
\hline Terbutaline $(10 \mu \mathrm{M})$ & $154.4 \pm 69^{\ddagger}$ & $<0.3$ \\
\hline Forskolin $(10 \mu \mathrm{M})$ & $132.9 \pm 32.5^{*}$ & $0.4 \pm 0.1$ \\
\hline Terbutaline + dexamethasone & $233.8 \pm 55.1^{*}$ & $16.1 \pm 13.9^{*}$ \\
\hline Forskolin + dexamethasone & $259.2 \pm 81.9^{*}$ & $8.7 \pm 2.8^{*}$ \\
\hline
\end{tabular}

Explants were cultured for $3 \mathrm{~d}$ with addition of hormones for the last $48 \mathrm{~h}$ of culture. Data are mean $\pm \mathrm{SE}$ for three to five experiments.

$* P<0.005$ vs. control.

${ }^{\ddagger} P=0.16$ vs. control. 
more rapid than for SP-C mRNA, and maximal levels in treated cultures occurred after 2 and $6 \mathrm{~d}$ of culture, respectively (e.g., Fig. 5). Induction of both mRNAs was reversible; sustained stimulation required the continuous presence of glucocorticoid. The different kinetics for induction and deinduction of SP-B and SP-C mRNAs could be due to differences in the mechanism of glucocorticoid action and/or mRNA stability. Additional studies will be required to determine whether the genes are directly activated by glucocorticoid-receptor complex or whether induction is mediated by other glucocorticoid-induced proteins.

Induction of both mRNAs also occurred with natural corticosteroids. By contrast, sex steroids had no effect. We found similar results in earlier studies with human lung examining the rate of choline incorporation into phosphatidylcholine (24). The stimulatory effect of cortisone, which has no intrinsic glucocorticoid activity, was not unexpected, since lung tissue contains $11 \beta$-hydroxysteroid dehydrogenase which catalyzes interconversion of cortisone and cortisol $(29,31)$.

Dose-response patterns to glucocorticoid were different for the two mRNAs. Half-maximal stimulation with dexamethasone occurred at approximately fivefold lower concentrations for SP-B mRNA than for SP-C mRNA. The dose-response pattern for SP-B mRNA is similar to that recently observed for dexamethasone stimulation of fatty acid synthetase activity (half maximal at $\sim 2 \mathrm{nM}$ ) in human lung explants (32). Induction of SP-A is also half maximal at 1-2 $\mathrm{nM}$ dexamethasone, but stimulation decreases at concentrations $>10 \mathrm{nM}$ (33). For comparison, the $K_{d}$ for dexamethasone binding in intact lung cells at $37^{\circ} \mathrm{C}$ is $5-16 \mathrm{nM}(34,35)$. The response curves for cortisol indicated half-maximal effects at $\sim 300$ and $1,000 \mathrm{nM}$ for SP-B and SP-C mRNA, respectively. The decreased potency of cortisol compared with dexamethasone is consistent with its lower binding affinity for receptor and with partial metabolism to cortisone during culture.

The dose-response findings could be accounted for if induction of SP-B mRNA (concentration of dexamethasone for half-maximal stimulation < receptor $K_{d}$ ) but not SP-C mRNA (for which half-maximal concentration $\cong K_{d}$ ) were amplified by induction of other protein(s) that increase gene transcription or mRNA stability. Alternatively, the apparent dose-response differences could arise from differences in the kinetics of response for the two genes.

cAMP has been shown to affect other components of the surfactant system. Synthesis of both phosphatidylcholine (as assessed by choline incorporation) and SP-A are stimulated by cAMP analogues, $\beta$-adrenergic agonists, and other agents that increase intracellular CAMP (forskolin and inhibitors of cAMP phosphodiesterase) $(16,18,19,33,36)$. At doses of terbutaline and forskolin that were optimal for stimulation of SP-A, we found increased levels of SP-B mRNA but not SP-C mRNA. The induction of SP-B mRNA by these agents was less than that seen with dexamethasone, and additive effects were not apparent. Whitsett et al. (20) reported some increase in both SP mRNAs by 8-bromo-cAMP but no apparent effect on content of the proteins as measured by ELISA assay.

We have not examined synthesis of the hydrophobic proteins per se in this study. In the report by Whitsett et al. (20) studies of protein synthesis and processing were carried out with an antiserum that appears to react with both SP-B and SP-C precursors. These workers found that dexamethasone treatment of lung explants increased $\left[{ }^{35}\right.$ S $]$ methionine incorpo- ration into immunoprecipitable proteins of $M_{\mathrm{r}}=42,000$ and 25,000 , which presumably represent the precursor proteins for SP-B and SP-C, respectively. Thus, it is likely that the changes in mRNA levels described in the present study also reflect synthesis of both precursor proteins. The type and amount of processing of these proteins in the culture system is not yet defined.

In summary, we have found that expression of the genes for the two hydrophobic surfactant proteins begins during the second trimester of human gestation. Although both mRNAs increase with development, the two genes appear to be independently regulated. During explant culture without serum or hormones the level of SP-B mRNA increases, whereas SP-C mRNA decreases. Both mRNAs are induced by glucocorticoids by processes involving receptors; however, differences in glucocorticoid potency and in the time courses for induction indicate that the responses may involve different mechanisms of pretranslational regulation. The two mRNAs also differ in their response to agents that increase intracellular cAMP.

Glucocorticoid treatment accelerates lung development in fetal animals and reduces the incidence of hyaline membrane disease in premature human infants. Increased production of pulmonary surface active phospholipids is a critical aspect of this response. The results of this and other recent studies suggest that glucocorticoids also simulate synthesis of the three proteins associated with surfactant.

\section{Acknowledgments}

We thank Phyllis Ponte for providing cDNA probe for actin; Serge Bottari and Henry Bourne for providing cDNA probe for $\mathrm{G}_{s \alpha}$; Robert Ertsey, Madeleine Huey, and Dan Latham for technical assistance; and Carol Dahlstrom for preparation of the manuscript.

This work was supported by the National Institutes of Health grants HL-27356, HL-24075, and HL/HD-30541. Dr. Liley was a recipient of a Julius $\mathrm{H}$. Comroe fellowship.

\section{References}

1. Possmayer, F. 1988. Perspective: a proposed nomenclature for pulmonary surfactant-associated proteins. Am. Rev. Respir. Dis. 138:990-998.

2. Hawgood, S., B. J. Benson, J. Schilling, D. Damm, J. A. Clements, and R. T. White. 1987. Nucleotide and amino acid sequences of pulmonary surfactant protein SP 18 and evidence for cooperation between SP 18 and SP 28-36 in surfactant lipid adsorption. Proc. Natl. Acad. Sci. USA. 84:66-70.

3. Warr, R. G., S. Hawgood, D. I. Buckley, T. M. Crisp, J. Schilling, B. J. Benson, P. L. Ballard, J. A. Clements, and R. T. White. 1987. Low molecular weight human pulmonary surfactant protein (SP-5): isolation, characterization, and cDNA and amino acid sequences. Proc. Natl. Acad. Sci. USA. 84:7915-7919.

4. Takahashi, A., and T. Fujiwara. 1986. Proteolipid in the bovine lung surfactant: its role in surfactant function. Biochem. Biophys. Res. Commun. 135:527-532.

5. Yu, S.-H., and F. Possmayer. 1986. Reconstitution of surfactant activity by using the $6 \mathrm{kDa}$ apoprotein associated with pulmonary surfactant. Biochem. J. 236:85-89.

6. Whitsett, J. A., B. L. Ohning, G. Ross, J. Meuth, T. Weaver, B. A. Holm, D. L. Shapiro, and R. H. Notter. 1986. Hydrophobic surfactant-associated protein in whole lung surfactant and its importance for biophysical activity in lung surfactant extracts used for replacement therapy. Pediatr. Res. 20:460-467.

7. Tanaka, Y., T. Takei, T. Aiba, K. Masuda, A. Kiuchi, and T. Fujiwara. 1986. Development of synthetic lung surfactants. J. Lipid Res. 27:475-485. 
8. Revak, S. D., T. A. Merritt, E. Degryse, L. Stefani, M. Courtney, M. Hallman, and C. G. Cochrane. 1988. Use of human surfactant low molecular weight apoproteins in the reconstitution of surfactant biological activity. J. Clin. Invest. 81:826-833.

9. Jacobs, K. A., D. S. Phelps, R. Steinbrink, J. Fisch, R. Kriz, L. Mitsock, J. P. Dougherty, H. W. Taeusch, and J. Floros. 1987. Isolation of a cDNA clone encoding a high molecular weight precursor to a $6 \mathrm{kDa}$ pulmonary surfactant-associated protein. J. Biol. Chem. 262:9808-9811.

10. Glasser, S. W., T. R. Korfhagen, T. E. Weaver, J. C. Clark, T. Pilot-Matias, J. Meuth, J. L. Fox, and J. A. Whitsett. 1988. cDNA, deduced polypeptide structure and chromosomal assignment of human pulmonary surfactant proteolipid. J. Biol. Chem. 263:9-12.

11. Glasser, S. W., T. R. Korfhagen, T. E. Weaver, T. Pilot-Matias, J. L. Fox, and J. A. Whitsett. 1987. cDNA and deduced amino acid sequence of human pulmonary surfactant-associated proteolipid SPL(Phe). Proc. Natl. Acad. Sci. USA. 84:4007-4011.

12. Emrie, P. A., C. Jones, and J. A. Fisher. 1988. The coding sequence for the human 18,000 dalton hydrophobic pulmonary surfactant protein is located on chromosome 2 and identifies a restriction fragment length polymorphism. Somatic Cell Mol. Genet. 14:105-110.

13. Ballard, P. L. 1986. Hormones and Lung Maturation. Springer-Verlag, Heidelberg, FRG. 354 pp.

14. Ballard, P. L., S. Hawgood, H. Liley, G. Wellenstein, L. W. Gonzales, B. Benson, B. Cordell, and R. T. White. 1986. Regulation of pulmonary surfactant apoprotein SP 28-36 gene in fetal human lung. Proc. Natl. Acad. Sci. USA. 83:9527-9531.

15. Liley, H. G., S. Hawgood, G. A. Wellenstein, B. Benson, R. T. White, and P. L. Ballard. 1987. Surfactant protein of molecular weight 28,000-36,000 in cultured human fetal lung: cellular localization and effect of dexamethasone. Mol. Endocrinol. 1:205-215.

16. Odom, M. J., J. M. Snyder, and C. R. Mendelson. 1987. Adenosine 3',5'-monophosphate analogs and beta-adrenergic agonists induce the synthesis of the major surfactant apoprotein in human fetal lung in vitro. Endocrinology. 121:1155-1163.

17. Phelps, D. S., S. Church, S. Kourembanas, H. W. Taeusch, and J. Floros. 1987. Increases in the $35 \mathrm{kDa}$ surfactant-associated protein and its mRNA following in vivo dexamethasone treatment of fetal and neonatal rats. Electrophoresis. 8:235-238.

18. Whitsett, J. A., T. Pilot, J. C. Clark, and T. E. Weaver. 1987. Induction of surfactant protein in fetal lung. J. Biol. Chem. 262:52565261.

19. Boggaram, V., K. Qing, and C. R. Mendelson. 1988. The major apoprotein of rabbit pulmonary surfactant. J. Biol. Chem. 263:1-9.

20. Whitsett, J. A., T. E. Weaver, J. C. Clark, N. Sawtell, S. W. Glasser, T. R. Korfhagen, and W. M. Hull. 1987. Glucocorticoid enhances surfactant proteolipid Phe and pVal synthesis and RNA in fetal lung. J. Biol. Chem. 262:15618-15623.

21. Mendelson, C. R., C. Chen, V. Boggaram, C. Zacharias, and J. M. Snyder. 1986. Regulation of the synthesis of the major surfactant apoprotein in fetal rabbit lung tissue. J. Biol. Chem. 261:9938-9943.

22. Whitsett, J. A., T. E. Weaver, M. A. Lieberman, J. C. Clark, and C. Daugherty. 1987. Differential effects of epidermal growth factor and transforming growth factor-beta on synthesis of $M_{\mathrm{r}}=35,000$ surfactant-associated protein in fetal lung. J. Biol. Chem. 262:7908-7913.

23. Snyder, J. M., and C. R. Mendelson. 1987. Insulin inhibits the accumulation of the major lung surfactant apoprotein in human fetal lung explants maintained in vitro. Endocrinology. 120:1250-1257.

24. Gonzales, L. W., P. L. Ballard, R. Ertsey, and M. C. Williams. 1986. Glucocorticoids and thyroid hormones stimulate biochemical and morphological differentiation of human fetal lung in organ culture. J. Clin. Endocrinol. Metab. 62:678-691.

25. Ballard, P. L., R. Ertsey, L. K. Gonzales, H. G. Liley, and M. C. Williams. 1986. Isolation and characterization of differentiated alveolar type II cells from fetal human lung. Biochim. Biophys. Acta. 883:335-344.

26. White, B. A., and F. C. Bancroft. 1982. Cytoplasmic dot hybridization. Simple analysis of relative mRNA levels in multiple small cell or tissue samples. J. Biol. Chem. 257:8569-8572.

27. Sullivan, K. A., Y.-L. Liao, A. Alborzi, B. Beiderman, F.-H. Chang, S. B. Masters, A. D. Levinson, and H. R. Bourne. 1986. Inhibitory and stimulatory $G$ proteins of adenylate cyclase: cDNA and amino acid sequences of the alpha chains. Proc. Natl. Acad. Sci. USA. 83:6687-6691.

28. Gunning, P., P. Ponte, H. Okayama, J. Engel, H. Blau, and L. Kedes. 1983. Isolation and characterization of full-length $\mathrm{cDNA}$ clones for human alpha, beta, and gamma-actin mRNAs: skeletal but not cytoplasmic actins have an amino-terminal cysteine that is subsequently removed. Mol. Cell Biol. 3:787-795.

29. Ballard, P. L., R. A. Ballard, L. K. Gonzales, R. Hummelink, C. M. Wilson, and I. Gross. 1984. Corticosteroid binding by fetal rat and rabbit lung in organ culture. J. Steroid Biochem. 21:117-126.

30. Phelps, D. S., and J. Floros. 1988. Localization of surfactant protein synthesis in human lung by in situ hybridization. Am. Rev. Respir. Dis. 137:939-942.

31. Abramovitz, M., C. L. Branchaud, and B. E. P. Murphy. 1982. Cortisol-cortisone interconversion in human fetal lung: contrasting results using explant and monolayer cultures suggest that 11 beta-hydroxysteroid dehydrogenase (EC 1.1.1.146) comprises two enzymes. $J$. Clin. Endocrinol. Metab. 54:563-568.

32. Gonzales, L. W., P. L. Ballard, R. Ertsey, and D. Froh. 1988. Effects of dexamethasone (dex) and cAMP on fatty acid synthetase in human fetal lung explants. Fed. Proc. 2:492A. (Abstr.)

33. Liley, H. G., R. T. White, B. J. Benson, and P. L. Ballard. 1988. Glucocorticoids both stimulate and inhibit production of pulmonary surfactant protein A in fetal human lung. Proc. Natl. Acad. Sci. USA. 85:9096-9100.

34. Ballard, P. L., and R. A. Ballard. 1974. Cytoplasmic receptor for glucocorticoids in lung of the human fetus and neonate. J. Clin. Invest. 53:477-486.

35. Ballard, P. L., R. J. Mason, and W. H. J. Douglas. 1978. Glucocorticoid binding by isolated lung cells. Endocrinology. 102:1570-1575.

36. Gross, I., C. M. Wilson, L. D. Ingleson, A. Brehier, and S. A. Rooney. 1980. Fetal lung in organ culture. III. Comparison of dexamethasone, thyroxine, and methylxanthines. J. Appl. Physiol. 48:872877. 